\title{
Gender differences in Assessments of Party Leaders
}

Kosiara-Pedersen, Karina; Hansen, Kasper Møller

Published in:

Scandinavian Political Studies

DOI:

10.1111/1467-9477.12033

Publication date:

2015

Document version

Early version, also known as pre-print

Citation for published version (APA):

Kosiara-Pedersen, K., \& Hansen, K. M. (2015). Gender differences in Assessments of Party Leaders.

Scandinavian Political Studies, 38(1), 26-48. https://doi.org/10.1111/1467-9477.12033 


\title{
Gender differences in assessments of party leaders ${ }^{1}$
}

\author{
Karina Kosiara-Pedersen \& Kasper M. Hansen ${ }^{2}$
}

Is there a relationship between party leader gender and voters' assessments? Yes, according to theses on gender identity and stereotyping. A voter survey during the 2011 Danish general election allows for a comprehensive analysis of a less likely case with four male and four female party leaders. Female party leaders are assessed more positively by female voters than male voters both in regard to general party leader sympathy and assessment of specific characteristics, whereas it is not the case that male party leaders are assessed more positively by male voters than female voters. The impact of gender does not increase with age, actually, the opposite is the case among men since younger male voters have smaller sympathy for female party leaders. Furthermore, there is no support for the expectation that voters with more education or with higher levels of political interest and knowledge are more positive towards party leaders of their own gender than voters with less education. Also, the relationship between gender and voters' assessments is not stronger prior to the election campaign than immediately after the election. Hence, in sum, gender identity does not seem to require a higher level of political sophistication nor does it decrease with higher levels of information.

Party leaders increasingly play a central role in campaigns and party images. Although political issues, party identification and party sympathy significantly affect electoral choices, party leadership also has an impact in the US and elsewhere (Wattenberg 1991; Hayes \& McAllister 1997; Thomsen 2003; Andersen \& Borre 2007; Garzia 2011; Bittner 2011). Combined with the documented effects of gender ${ }^{3}$ on political behavior and the presence of both female and male party leaders, this consideration has led to studies of gender and party leadership (Alexander \& Andersen 1993; Hayes \& McAllister 1997; Banducci \& Karp 2000; O’Neill \& Stewart 2009; Denemark et al. 2012). The limited number of cases available has constrained such studies, but the Danish case strengthens this research field. Not only do women make up half of the party leaders in Denmark, facilitating gender-focused analysis, but it is also an interesting and relevant case that provides new insights into the relationship between assessments of gender and party leaders before and after election campaigns.

Research is frequently conducted in the US context, which is a candidate-centered two-party system. However, European multiparty parliamentarian systems display a different degree of party choice and party-centeredness. Voters can choose from more parties, and some of these parties are ideologically close to each other, enabling factors other than political preferences to affect voter choice. Although parliamentarian systems have also become more candidate-centered (Karvonen 2010) and presidential due to the dynamics of media systems, European integration and party organizational challenges (Poguntke \& Webb 2005), they are still more party-centered than the US. Furthermore, in Scandinavian political systems, women are well integrated compared to those in other regions, and a high level of gender equality exists (Bergqvist et al. 1999; Bengtsson et al. 2013). Therefore, this study aims to explore whether voters' assessments of party leaders vary based on gender in the Danish case and to test existing theories that are frequently applied in research on gender and electoral studies on this party-centered, less likely case. 
Furthermore, this study explores electoral consequences in a different way than previous studies of gender and political office as it explicitly analyzes whether information about party policies, candidates and party leaders provided during electoral campaigns changes the impact of gender, decreasing gender differences in assessments of party leaders.

The theoretical basis and hypotheses explored here are presented below and followed by a presentation of the voter survey and Danish case studied. The analysis is divided into three sections: gender differences in voters' sympathy toward party leaders; gender differences in the impact of age, education, political interest and knowledge on party leader sympathy; and gender differences in voters' assessments of specific party leader characteristics. The results are concluded upon and discussed in the final section.

\section{Gender and party leadership}

Previous studies have indicated gender differences in the political behavior of the electorate. Gender differences in party choice and voting are found both in presidential-style systems, such as the US, and in parliamentarian systems allowing the electorate to vote for a specific candidate (Zipp \& Plutzer 1985; Huddy \& Terkildsen 1993a; Plutzer \& Zipp 1996; Sanbonmatsu 2002; Holli \& Wass 2010; Giger et al. 2014). Gender gaps in voting patterns might result from differences in ideological positions and policy opinions (see e.g. Togeby 1994; Studlar et al. 1998; Inglehart \& Norris 2000), perception of sex roles (Hershey 1977, 1980), as well as gender identity and gender stereotyping focused upon here.

"Identity politics" is defined as "political allegiances formed on the basis of some demographic similarity" (Plutzer \& Zipp 1996: 31; cf. Pomper 1975; Zipp \& Plutzer 1985). Social identity theory argues that social identity may affect the opinions and attitudes of an individual. If women consider belonging to the social group "women" important, they may choose to vote for a woman without necessarily considering political opinions and personal characteristics (Zipp \& Plutzer 1985). Because women may believe that a female representative is more likely to address their interests, this relates descriptive and substantive representation (cf. Pitkin 1967; Rosenthal 1995). This implies that women are choosing rationally to vote for a woman candidate. On this basis voters are more positive in their evaluation of same-gender candidates, meaning that female voters often prefer female candidates and male voters often prefer male candidates. The conditions under which social identity may have an impact are, most importantly, that both one's own "in" group and an "out" group are present. Gender identity may not affect votes if candidates represent only one gender. Hence, the understanding of gender identity applied here is that the gender of the voter has an impact on their political behavior and hence also on how they assess party leaders.

An additional reason for gender gaps in voters' political behavior is gender stereotyping, whereby voters attribute certain gender-dependent characteristics to political officeholders. Gender differences are found among both voters and officeholders. In other words, gender differences among voters affect the traits that they assign to candidates, candidates are met with gender- 
stereotypical expectations, and candidate gender is used to shape assessments of candidates' characteristics and competence (Huddy \& Terkildsen 1993a, 1993b; Alexander \& Andersen 1993; Kahn 1994; Matland 1994; Johns \& Shephard 2007).

The mechanisms of stereotyping and gender identity are expected to apply both to choice of candidates and parties and to assessments of party leaders. Previous research on voters' assessments of party leadership supports this conclusion by revealing that women tend to rate female party leaders higher than men do (O’Neill 1998; Banducci \& Karp 2000; Erickson 2003; Denemark et al. 2012; Bittner undated).

Assessments of party leaders may be both general and specific. Voters' general assessments of party leaders may be determined based on their sympathy toward party leaders. This sympathy may encompass aspects that vary among voters, and it is expected to be closely related to voters' partisanship because party leaders personify their parties and represent the party in the media. Voters' assessments of specific characteristics are expected to be less closely related to partisanship. These specific assessments are expected to yield a more nuanced picture of voters' assessments of party leaders. Therefore, voters' assessments of specific party leader characteristics are also relevant to this study. Studies of gender stereotyping have included various parameters when considering specific characteristics, a variation that has affected the results (Schneider \& Bos 2013). Including context-dependent gender-stereotypical female, male and neutral characteristics in such an analysis is therefore necessary.

The stereotypically female traits that the electorate attributes to female candidates differ from the traits that the voters consider appropriate for officeholders and candidates, which has been regarded as a disadvantage for female candidates. The traits deemed necessary to hold office are more similar to stereotypically male traits. This reality provides female candidates with a paradox whereby emphasizing their female traits may decrease their chances of being elected, but emphasizing male traits may backfire when their contradiction of stereotypical expectations leads voters to find them untrustworthy (Okimoto \& Brescoll 2010; Huddy \& Terkildsen 1993b). Previous studies have demonstrated that male and female voters emphasize different characteristics when judging candidates. Female voters emphasize compassion, caring and sensibility, whereas male voters emphasize assertion, vigor and strong leadership (Hayes \& McAllister 1997; Denemark et al. 2012).

Based on the gender identity thesis and gender stereotyping, the first hypothesis to be tested here is that male party leaders are assessed more positively by male voters than female voters, and female party leaders are assessed more positively by female voters than male voters $\left(\mathrm{H}_{1}\right)$.

Gender identity is not expected to matter equally to all voters. First, differences in life experiences and childhood socialization suggest that differences exist between age groups. In particular, Rosenthal (1995) demonstrates that the gender gap is more predominant among the "baby boomers," who matured when feminism was strong and whose experiences in the workplace and family life have made them more focused on female representation (1995: 602). These baby 
boomers, some of whom were on the front lines of the Danish "Red Stocking" movement, have matured, but they are expected to have retained their feminist attitudes. Their younger sisters in their forties have also to various degrees gained life experience from workplaces, chore distribution within families and possibly single motherhood, according to Rosenthal (1995), and they are therefore expected to have been awakened to feminism. The youngest generation to a larger extent lacks these life experiences and generally appears less interested in feminism and gender identity. Similarly, male socialization is also expected to have had an impact on party leader assessments since older men have been politically socialized at a time when politics was male dominated. Therefore, the hypothesis is that the older the voter, the more positive the voter is towards party leaders of their own gender $\left(\mathrm{H}_{2}\right)$.

Second, education is also expected to be related to the extent to which gender identity matters to voters when they assess party leaders. Carroll argues in her autonomy thesis that women's political autonomy is the result of psychological autonomy enabling women to develop independent political preferences, and economic independence (1988; Rosenthal 1995). One way, in which women gain both psychological and economic independence, is through education. Longer educated women are expected to have a higher degree of political autonomy. This leaves more room for the impact of gender identity. Furthermore, it requires some level of 'political sophistication' to mobilize gender identity (Wauters et al. 2013). Hence, the hypothesis is that the more education a voter has, the more positively the voter perceives party leaders of his or her own gender $\left(\mathrm{H}_{3}\right)$.

Third, political interest and knowledge are also expected to affect party leader sympathy. On the one hand, based on the gender identity thesis and gender stereotyping, or a combination of both, candidate gender provides a shortcut to assessments of candidates. Socio-demographic characteristics provide cues or heuristic shortcuts for voters who lack sufficient information on policies and candidate characteristics to make a choice based on their political preferences (Alexander \& Andersen 1993; Cutler 2002). Hence, it could be argued that voters with a higher level of political interest and knowledge are less likely to use the gender shortcut than voters with a lower level of political interest and knowledge. On the other hand, due to the relationship between education, political interest and knowledge, such a hypothesis would contradict the hypothesis above. Furthermore, and more importantly, based on similar arguments as regards the relationship between education and party leader sympathy, gender identity could also be argued to have a larger impact, the more political interest and knowledge the voter has. It requires some level of 'political sophistication' to mobilize the gender identity (Wauters et al. 2013). Thus, the hypothesis is that the more political interest and knowledge a voter has, the more positively the voter perceives party leaders of his or her own gender $\left(\mathrm{H}_{4}\right)$.

At the macro level the use of shortcuts such as gender identity and gender stereotyping, also labeled 'less sophisticated voting' is more likely in contexts with less political information (Dolan 1998; Johns \& Shephard 2007). Spatial comparisons across systems with various levels of political information, e.g. due to media systems, are expected to demonstrate that gender matters more in systems with low levels of information. Similarly, within systems, gender is expected to be more important at those levels of government where voters have less knowledge and access to 
information, such as at the local levels (cf. Alexander \& Andersen 1993). In addition, within-system cross-temporal comparisons yield differences in the effect of gender if the level of political information varies, as it does in periods prior to electoral campaigning and during election campaigns. Previous studies indicate that voters gain knowledge during campaigns (e.g., Freedman et al. 2004; Craig et al. 2005). Therefore, the final hypothesis is that the effects of gender on voters' assessments of party leaders are more significant before the election campaign than after election $\operatorname{day}\left(\mathrm{H}_{5}\right)$.

\section{Methods, the Danish case and data}

Analyzing gender differences is impossible outside the experimental world without the representation of both male and female party leaders. The lack of research into the effect of gender on party leadership may be explained by the lack of variation in the independent variable; women have comprised only a small share of party leaders (cf. Banducci 2002: 50). However, this is not the case in Denmark. At the 2011 general election, the gender balance was complete among party leaders of the parties that gained representation; four parties were led by men and four by women.

Therefore, the Danish case makes it possible to analyze voters' assessments of male and female party leaders from eight parties across the political spectrum. Analyzing voters' assessments of Danish party leaders is also relevant and interesting for several reasons.

First, the Danish multiparty parliamentarian system is party-centered, and partisanship is expected to underpin assessments of party leaders much more than gender. In general, the partisan label is strong compared to other systems, such as the American candidate-centered system. National-level candidates are not elected without a party label, and parties also dominate elections at the regional and local levels. Candidates are recruited through parties, particularly through membership organizations (Pedersen 2003). Only half the Danish voters vote for a specific candidate on a party's list; the other half simply vote for the party (Bengtsson et al. 2013: 83; Hansen 2014). Party leaders are also groomed by their parties, and no Danish party leader has 'hijacked' a party as depicted in the franchise party model (cf. Carty 2004).

Second, Scandinavian women are well integrated into their countries' political systems compared to women in other countries (Bergqvist et al. 1999; Raaum 2004; Heidar \& Pedersen 2006). Leaders of four of the eight parties represented in Danish parliament are women, and they appear on both sides of the political spectrum. Furthermore, several parties have female political spokespersons who also assume prominent positions in their parties' public images because they appear frequently in the media. Women are well represented in government and comprise 39 percent of the parliamentarians at the national level (Folketinget 2014). In sum, the gender gap is expected to be smaller in Danish politics because women are present.

Third, Danish politics seem less feminized than politics in Norway and Sweden (Borchorst 2011). Danish parties have previously applied gender quotas less frequently than their Nordic counterparts (Christensen 1999), and presently there are no electoral quotas, and only the Social Democrats have 
gender quotas for party leadership. ${ }^{4}$ Although Nordic political systems are fairly similar, the Danish electorate is less likely to be mobilized by gender than voters in Norway and Sweden because feminism and gender equality are lower on the Danish political agenda.

Compared to the rest of Europe, Scandinavia, and the US, gender gaps among the electorate are least likely in Denmark. The focus on party leaders also makes gender gaps in voters' assessments less likely when compared to candidates at various lower levels. Party leaders at the national level are well known by the public. As personifications of their parties, they often appear on television and in other media. In addition to political coverage, the more entertaining parts of the media also feature party leaders. Therefore, voters are expected to have gained some knowledge of these party leaders and are less likely to need the gender cue shortcut that contributes to gender gaps. The argument here is that the level of information about party leaders is higher than about candidates, hence, there is less room for the effect of gender identity notwithstanding gendered media coverage in both the entertaining and more serious parts of the media (see e.g. van Zoonen 1998; 2005; 2006; Campus 2013), since gendered media coverage happens to both leaders and candidates.

In sum, studying the effect of gender on voters' assessments of party leaders of eight Danish parties is both possible and highly interesting.

\section{The Danish case}

The Danish parties included in the analyses are those represented in parliament, Folketinget, in 2011. ${ }^{5}$ The parties are listed in Table 1 in order of their political orientation from left to right, with the name, abbreviation, party leader, party leader gender, vote share in 2011 election and government participation before and after the 2011 election.

Table 1 The Danish parties 2011

\begin{tabular}{llcrc}
\hline Party (abbreviation) & $\begin{array}{l}\text { Party Leader } \\
\text { (abbreviation) }\end{array}$ & $\begin{array}{c}\text { Gender } \\
\text { Vote Share } \\
\end{array}$ & $\begin{array}{c}\text { Government } \\
\text { participation } \\
\text { before/after } \\
2011 \text { election }\end{array}$ \\
\hline \hline Red-Green Alliance (RGA) & Johanne Schmidt-Nielsen & Woman & 6.7 & $-/-$ \\
Socialist People's Party (SPP) & Villy Søvndal & Man & 9.2 & $-/+$ \\
Social Democrats (SD) & Helle Thorning-Schmidt & Woman & 24.8 & $-/+$ \\
Social Liberals (SL) & Margrethe Vestager & Woman & 9.5 & $-/+$ \\
Conservative People's Party (CPP) & Lars Barfoed & Man & 4.9 & $+/-$ \\
Liberal Party (LP) & Lars Løkke Rasmussen & Man & 26.7 & $+/-$ \\
Danish People's Party (DPP) & Pia Kjærsgaard & Woman & 12.3 & $-/-$ \\
Liberal Alliance (LA) & Anders Samuelsen & Man & 5.0 & $-/-$ \\
\hline \hline
\end{tabular}

Note: Parties are placed in left-right order on the economic, redistributive scale. Party leaders at the time of the Danish General Election, 2011. Election result source is The Electoral Office of the Ministry of the Interior.

Danish parties lack a long tradition of female party leadership. The four parties that are more than 100 years old include the Social Liberals, which have had female leaders since 1990 (with a shift in 2007); the Social Democrats, which elected a woman for the first time in 2005 and the Conservatives, who had a female chair from 2005 to 2011 (prior to the election). During the 2011 
election, two of the four newer parties had a female leader. As party founder, Pia Kjærsgaard has been the natural leader of the Danish People's Party since its establishment in 1996. The Red-Green Alliance does not have a formal party leader but chose in 2009 to select a female political spokesperson. ${ }^{6}$ In sum, the share of female party leaders has increased quickly within a short time span.

Danish parties vary in the formal position of the party leader, including whether they are elected or selected and whether the member-organization or parliamentary group is decisive (Bille 1997; party statutes). In the parties where the parliamentary group has been decisive in party leader selection, two men and three women serve as party leaders. In the two parties where the party members are decisive, one man and one woman serve as party leaders at the time of this study. In the last party, the party leadership is assumed by the party founder, a woman. In sum, no relationship exists between (s)election method and gender in Danish politics. ${ }^{7}$

The gender balance among Danish party leaders at the time of this study in 2011 is not due to the application of gender quotas since they are used very limited, and when used, in the case of the Social Democrats, could be argued not to have had an effect on the present, female, party leader, Helle Thorning-Schmidt, since she was not previously vice leader. Furthermore, the gender of the party leader does not appear to have played a role in the parties' (s)election processes. Danish political parties have many factors to consider when electing or selecting party leaders. Electoral appeal is very important but not the only factor. Depending on the current situation and the parties' immediate and long-term goals, parties need leaders who are skilled at political negotiations, maintaining or establishing party cohesion, fundraising, and organizational leadership and change. Party leaders are (s)elected from a limited pool of potential candidates within each party; not all competencies may be present in one candidate.

Danish election studies demonstrate that no clear tendency for how men and women vote existed in the 1960s and 1970s, but women since then have voted for the Socialist parties, including the Social Democrats and left-wing parties, more frequently than men (Andersen \& Andersen 2003: 190; Stubager \& Hansen 2013: 65). This shift from the center-right to the left is a general, but not universal, phenomenon (Inglehart \& Norris 2000). Women's left-leaning tendency still exists, as indicated in Table 2, where the Social Liberals are grouped with the socialist parties. Furthermore, the gender gaps among the parties' electorates are small for several parties, including the RedGreen Alliance, Social Democrats, Social Liberals and Danish People's Party. Gender gaps among the electorates of the other parties are more pronounced. The Socialist People's Party stands out as female dominated, whereas the Liberal Alliance and Conservatives are male dominated. The Liberals also have a small majority of men within their electorate. Since there is no long tradition of female party leaders, they cannot have caused this realignment of female voters to the left.

Gender gaps in party choice implies that it is necessary to control for this when explaining voters' level of party leader sympathy, as was also argued above. 
Table 2 The electoral choices of men and women at the 2011 general election, pct.

\begin{tabular}{|c|c|c|c|c|c|c|c|}
\hline & RGA & $\begin{array}{ll}\text { SPP } & \text { SD } \\
\end{array}$ & SL & $\mathrm{CP}$ & DPP & LA & Blanc and other \\
\hline Men & 4.1 & $\begin{array}{c}10.0 \quad 25.9 \\
45.8\end{array}$ & 5.8 & 6.7 & $\begin{array}{c}22.4 \\
51.5\end{array}$ & 9.8 & 2.6 \\
\hline Women & 4.4 & $\begin{array}{c}17.5 \quad 26.5 \\
53.7\end{array}$ & 5.4 & 3.8 & $\begin{array}{c}18.913 .2 \\
40.9\end{array}$ & 5.0 & 5.3 \\
\hline
\end{tabular}

Source: Online Panel of Electoral Campaigning (OPEC), Hansen et al. 2012

\section{The survey and variables}

The dataset that fuels this analysis is from an online panel survey conducted among a large sample of Danish voters before, during and after the general election September 15, 2011 (Hansen et al. 2012). ${ }^{8}$ The survey is generally representative for voters, except that respondents with little education are slightly underrepresented.

Two dependent variables are included in the analysis. First, party leader sympathy is assessed based on the question: "How good is your opinion of the leaders of the parties?" The voter is asked to rank each of the eight party leaders represented in parliament on a scale from 0 (very bad) to 10 (very good).

The second dependent variable is voters' assessments of specific characteristics of party leaders, based on the question: "How well do you think that the following characteristics fit [the party leader's name]?" The characteristics listed are trustworthiness, ability to inspire, knowledge, awareness of common people's opinions and thoughts, sincerity, qualification to be Prime Minister, good leadership and personal charisma. Voters offer assessments on an 11-point scale from 0 (very bad) to 10 (very good). The characteristics were not chosen with this specific research question in mind, but they are useful because they include both traditionally male stereotypical characteristics, such as good leadership, and traditionally female characteristics, such as sincerity and awareness of ordinary people (cf. Hayes \& McAllister 1997; Schneider \& Bos 2013). However, other characteristics, such as compassion and ability to care or toughness and ambition, would have been more appropriate because they are linked more clearly to gender stereotypes of women and men, respectively. Furthermore, voters are only asked about the characteristics of party leaders prior to the campaign. Therefore it is impossible to analyze whether the effects of gender on voters' assessments of party leaders are larger before the election $\left(\mathrm{H}_{5}\right)$.

Several independent variables are included in the analysis to explain voters' assessments of party leaders. The main independent variable is gender, assessed based on the question: "What is your gender?" with "man" or "woman" as possible answers. The second independent variable applied in the analysis is age, which is determined by asking voters to state when they were born.

Third, education is determined by asking voters to tick the highest level of education achieved. Responses fall into several categories from elementary school to post-graduate degrees. Voters' responses are dichotomized so that respondents with a short, medium or long college education are 
categorized with higher education (" 1 ") and all others with less than that ("0"). Therefore, "higher education" implies degrees such as policeman, dental hygienist, journalist, nurse, school teacher as well as all BA, MA and PhD university degrees (academic education until the respondents are 2330 years old).

Fourth, political interest and political knowledge are included in the analyses. Political interest is determined by responses to the question: "How interested in politics would you consider yourself to be?" Respondents place themselves on an 11-point scale from 0 (not interested at all) to 10 (very interested). Political knowledge ranges from 0 to 10 and is determined by voters' ability to place the parties on the traditional, economic left-right scale ranging from 0 to 10 . The existence of eight parties implies that 28 party-pair comparisons are possible when voters have placed all eight parties, and voters are given one point for all correct pair-wise placements. This $0-28$ scale of voters' scores is rescaled to $0-10$. The correct order of the parties along this scale is all respondents' average placement of the parties. This placement corresponds to experts' placement. This measure is applied because it has previously been demonstrated to be an accurate indicator of political knowledge (Hansen \& Pedersen forthcoming).

Men and women do not vote equally for all parties due to differences in ideological positions and policy opinions. Because voters are expected to assess leaders of preferred parties higher than other party leaders, and because male and female party leaders are not distributed equally across the political spectrum, including a measure for voters' relationship with the parties is necessary. Party choice could simply be included. However, within multiparty parliamentarian systems, parties are not isolated islands; some exist close to each other. Voters may have a similar level of sympathy for more than one party (Hansen \& Kosiara-Pedersen forthcoming). Another solution would be to group voters' party preferences in two categories based on their bloc vote, which indicates what side of the political spectrum voters prefer. However, because the political spectrum is not necessarily divided into two distinct blocs and because voters also shift between the blocs, bloc vote does not reflect the breadth of voters' party preferences.

Instead, party sympathy is included here. Voters have different degrees of sympathy for the various parties. In general, the farther away on the relevant political dimension the party is from the voter's preferred party, the smaller the party sympathy and vice versa (Hansen \& Kosiara-Pedersen forthcoming). Party sympathy is expected to be strongly correlated with voters' assessments of party leaders. Voters are expected, ceteris paribus, to value leaders of parties they sympathize with more than other party leaders; and vice versa, value parties of leaders they sympathize with more. Hence, the causality may go both ways. The gender identity thesis, gender stereotyping and gender as a cue may explain voters' assessments of party leaders, even considering their party sympathy. Party sympathy is assessed based on the question: "How good is your opinion of the parties?" The voter is asked to assess each of the eight parties represented in parliament on an 11-point scale from 0 (very bad) to 10 (very good). Contrary to party identification, which is a nominal indicator of whether a voter is close to just one party, voters' party sympathy is continuous measured for each party. Hence, all voters have a level of sympathy (scaled 0 and 10) for each of the eight parties. 


\section{Gender differences in party leader assessments among Danish voters}

Turning to the analyses, the overall question is whether gender differences exist in Danish voters' assessments of party leaders. The answer to this question is explored in three subsections below: gender differences in voters' party leader sympathy; gender differences in the impact of age, education, interest and knowledge on voters' sympathy toward party leaders; and gender differences in the characteristics that male and female voters attribute to male and female party leaders.

\section{Gender differences in party leader sympathy}

This first section analyzes gender differences in party leader sympathy. The dependent variables are the voters' average party leader sympathy for the four male party leaders and the voters' average party leader sympathy for the four female party leaders. The average is calculated to achieve strong reliability for the measure across male and female party leaders.

The first hypothesis to be explored is that male party leaders are assessed more positively by male voters than female voters, and female party leaders are assessed more positively by female voters than male voters $\left(\mathrm{H}_{1}\right)$. Table 3 indicates that without control for party sympathy, this hypothesis is supported for both male and female voters both before the campaign and after the election, i.e. male voters prefer male party leaders more than female voters do and vice versa. Furthermore, we can see the absolute effect size for the female party leaders are stronger than the one for male party leaders. This shows that the gender effect is the largest for female party leaders. However, no support is found for the hypothesis that the gender effects on voters' assessments of party leaders are larger before the election campaign than after election day $\left(\mathrm{H}_{5}\right)$. The coefficients before the campaign are not significantly different compared to the coefficients after the campaign.

Table 3 Modeling the party leader sympathy (without control for party sympathy)

(1)

Male party leaders (before)

Women

$-0.134 * * *$

$(0.04)$

Constant

$4.223 * * *$
(2)

Female party leaders (before)
(3)

Male party leaders (after)

$-0.0797^{*}$

$4.417 * * *$

\begin{tabular}{lllll} 
& $(0.03)$ & $(0.03)$ & $(0.03)$ & $(0.03)$ \\
\hline$N$ & 4,903 & 4,903 & 4,903 & 4,903 \\
$R^{2}$ & 0.002 & 0.021 & 0.001 & 0.031 \\
\hline
\end{tabular}

Note: OLS-regression, unstandardized coefficients, robust standard errors in parentheses, ${ }^{*} p<0.10, * * p<0.05, * * * p$ $<0.01$. 'Before' refer to a measure before the campaign and 'after' a measure just after the election was held.

However, as argued above, because gender gaps occur in voter choices, controlling for party sympathy is necessary. Therefore, Table 4 demonstrates the impact of gender after controlling for party sympathy. We simply do this by adding voters' average party sympathy for parties led by a man or a women. Naturally the party sympathy variables are strongly significant in all models in Table 4 which simply tells us that party and leader sympathy are strongly positively related. But what is interesting is whether voter gender remains significant after the strong control for party 
sympathy. We find that the gender effect becomes insignificant among male party leaders, but remains highly significant among female party leaders, and this is the case both prior to and after the election. Thus, support is found only for the latter part of the hypothesis $\left(\mathrm{H}_{1}\right)$; i.e. female party leaders are assessed more positive by women than men, but this difference does not exist when it comes to male party leaders. These results are consistent with previous studies that indicate that women tend to rate female party leaders higher than men, which has also been the case in Australian elections (1996, 2007, 2010), Britain (1979, 1987), Canada (1993, 1997) and New Zealand (1996) (O’Neill 1998; Banducci \& Karp 2000; Erickson 2003; Denemark et al. 2012). No support is found for the hypothesis $\left(\mathrm{H}_{5}\right)$ that the gender effects on voters' assessments of party leaders are more significant before the election campaign than after election day (as coefficients 95\% CI's are overlapping, not shown). This observation indicates that campaigning does not decrease the influence of gender in voters' assessments of female party leaders. Campaigning does not significantly decrease voters' dependence on gender identity and stereotyping; hence, voters rely on gender regardless of the level of information and/or sophistication, which is a result similar to that of Cutler (2002).

Table 4 Modeling the party leader sympathy (with control for party sympathy)

\begin{tabular}{lcccc}
\hline & $(1)$ & $(2)$ & $(3)$ & $(4)$ \\
& Male party leaders & Male party leaders & Female party & Female party \\
(before) & $($ after) & 0.00139 & $0.177^{* * *}$ & $0.0975^{* * *}$ \\
leaders (before) & $(0.03)$ \\
Women & 0.0126 & $(0.02)$ & $(0.03)$ & $(0.03)$ \\
Party sympathy & $(0.03)$ & $0.887 * * *$ & $0.921^{* * *}$ & $0.896^{* * *}$ \\
& $0.786^{* * *}$ & $(0.01)$ & $(0.01)$ & $(0.01)$ \\
Constant & $(0.01)$ & $0.421^{* * *}$ & $0.686^{* * *}$ & $0.945^{* * *}$ \\
& $0.825^{* * *}$ & $(0.04)$ & $(0.05)$ & $(0.04)$ \\
\hline$N$ & $(0.05)$ & 4,903 & 4,903 & 4,903 \\
$R^{2}$ & 4,903 & 0.705 & 0.633 & 0.697 \\
\hline
\end{tabular}

Note: OLS-regression, unstandardized coefficients, robust standard errors in parentheses, ${ }^{*} p<0.10,{ }^{*}{ }^{*} p<0.05,{ }^{* * *} p<0.01$.

The impact of age, education, interest and knowledge

This second section explores the impact of age, education, interest and knowledge on voters' sympathy toward party leaders to investigate the mechanism for gender identity and gender stereotyping. Therefore, this section explores whether the older the voter, the more positive the voter is towards party leaders of their own gender $\left(\mathrm{H}_{2}\right)$, whether voters with more education are more positive towards party leaders of their own gender than voters with less education $\left(\mathrm{H}_{3}\right)$, and whether the more political interest and knowledge a voter has, the more positively the voter perceives party leaders of his or her own gender $\left(\mathrm{H}_{4}\right)$. As in the previous two sections, this section also explores whether the gender effects on voters' assessments of party leaders are more significant before the election campaign than after election day $\left(\mathrm{H}_{5}\right)$. These hypotheses all need to be tested through interaction effects in the regressions models, e.g. conditioned on the voters' age, how is the effect of the voters' gender. 
To start this analysis we first present only the main effects of the variables (Table 5) without including any interactions in the models. Secondly, we expand the models with a full set of interactions among the independent variables. Table 5 shows that the results from Table 4 are consistent also when including more controls (age, education, political interest and knowledge). It also tells us that older voters have stronger sympathy for party leaders regardless of the party leader's gender. Increased education, political interest and political knowledge have a significant effect on the voters' female party leader sympathy before the campaign. After the campaign only political knowledge is significant. Among male party leaders no effect is found for education, political interest and political knowledge.

Table 5 Modeling the party leader sympathy (with control for party sympathy and SES)

\begin{tabular}{lcccc}
\hline & $(1)$ & $(2)$ & $(3)$ & $(4)$ \\
& Male party leaders & Male party leaders & Female party & Female party \\
(before) & $($ after) & leaders (before) & leaders (after) \\
\hline Women & 0.0211 & 0.0230 & $0.238^{* * *}$ & $0.124^{* * *}$ \\
& $(0.03)$ & $(0.02)$ & $(0.03)$ & $(0.03)$ \\
Age & $0.00418^{* * *}$ & $0.00363^{* * *}$ & $0.00572^{* * *}$ & $0.00223^{* *}$ \\
& $(0.00)$ & $(0.00)$ & $(0.00)$ & $(0.00)$ \\
Academic education & 0.0318 & -0.00468 & $0.0580^{*}$ & 0.0209 \\
& $(0.03)$ & $(0.02)$ & $(0.03)$ & $(0.03)$ \\
Political interest & -0.00927 & 0.00636 & $0.0303^{* * *}$ & 0.0104 \\
& $(0.01)$ & $(0.01)$ & $(0.01)$ & $(0.01)$ \\
Political knowledge & 0.00452 & 0.00438 & $0.0273^{* * *}$ & $0.0186^{* * *}$ \\
& $(0.01)$ & $(0.01)$ & $(0.01)$ & $(0.01)$ \\
Party sympathy & $0.787 * * *$ & $0.889 * * *$ & $0.913 * * *$ & $0.895^{* * *}$ \\
& $(0.01)$ & $(0.01)$ & $(0.01)$ & $(0.01)$ \\
Constant & $0.632^{* * *}$ & $0.150^{*}$ & -0.0491 & $0.600^{* * *}$ \\
& $(0.10)$ & $(0.09)$ & $(0.10)$ & $(0.09)$ \\
\hline$N$ & 4,903 & 4,903 & 4,903 & 4903 \\
$R^{2}$ & 0.592 & 0.707 & 0.639 & 0.699 \\
\hline
\end{tabular}

Note: OLS-regression, unstandardized coefficients, robust standard errors in parentheses. ${ }^{*} p<0.10, * * p<0.05$, $* * * p<0.01$.

In order to test whether gender interacts with age, education, political interest and knowledge we include a full set of interaction effects among the independent variables in our models in Table 5. We also include the interactions variable by variable but this yields the same results as when they are included together. It turns out that only one interaction across all independent variables in all of the four models in Table 5 shows an effect. The only effect found is in model 4, where a conditional effect of age across gender is found. No interaction effects of models 1, 2 and 3 in Table 5 show an effect.

As the full model give five-way interaction effects it makes sense to present them graphically rather than in table format. Figure 1 only shows the effect of the interactions from model 4, table 5 . The interaction effects of model 1, 2 and 3 in Table 5 are similar to those of model 4 depicted in Figure 1 , except that in model 4 , the interaction between age and gender is significant. 
Figure 1 Predicted probabilities based on model 4 in Table 5 including full set of interaction among independent variables
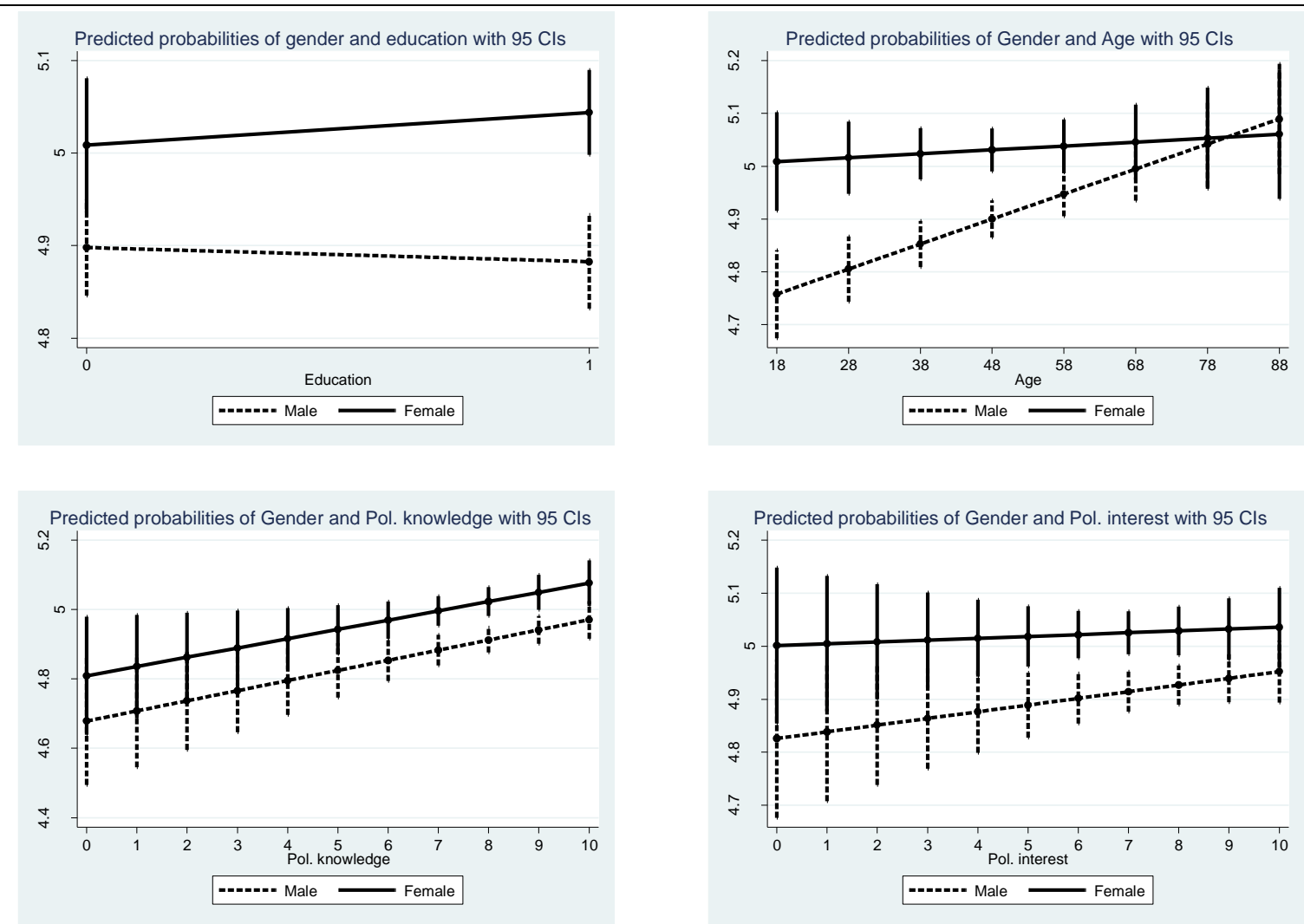

Note: Other variables are set at their mean when calculating the effects of the interaction variables.

In Figure 1 we see that for education, knowledge and political interest there is no conditional effect between the variables and gender, i.e. the effect of education, knowledge and interest is the same across gender. Thus we cannot find support for $\mathrm{H}_{3}$ and $\mathrm{H}_{4}$. Furthermore, the level of the coefficients are the same before and after the campaign (not shown in Figure) which implies that $\mathrm{H}_{5}$ is not confirmed.

In one of the four models we see a significant interaction effect between age and gender (Figure 1, gender and age). In this model, measured after the election, we find that young men assess female party leaders less positive than women, but this gender difference disappears for elderly voters. This finding is actually the opposite of $\mathrm{H}_{2}$ which stated that increasing age should increase the effect of gender on same-gender party leaders. Here we see a case of a decreasing effect of age for men when assessing female party leaders. This tells us that after the campaign it was especially young male voters that assessed female party leaders less positively. This is interesting as it points towards a possible hostility among younger men towards female leaders even if brought up and politically socialized in a more gender balanced context.

In sum, gender has an effect on party leader sympathy even when controlling for age, education, political interest and knowledge, but there is no relationship between the effect of gender and these 
variables. Except that younger men have less sympathy with female party leaders. Hence, we do not find support for the hypotheses that the older the voter, the more positive the voter is towards party leaders of their own gender $\left(\mathrm{H}_{2}\right)$, that voters with more education are more positive towards party leaders of their own gender than voters with less education $\left(\mathrm{H}_{3}\right)$, that the more political interest and knowledge a voter has, the more positively the voter perceives party leaders of his or her own gender $\left(\mathrm{H}_{4}\right)$, and that the gender effects on voters' assessments of party leaders are more significant before the election campaign than after election day $\left(\mathrm{H}_{5}\right)$.

\section{Gender differences in the attributed characteristics}

Because party leader sympathy is a general assessment, the electorate's assessments of characteristics of specific party leaders are included to allow for a more detailed assessment of whether the hypothesis about gender identity and gender stereotyping also applies to specifics less closely related to party sympathy. This section focuses on gender differences in the characteristics that male and female voters attribute to male and female party leaders. It explores whether male party leaders are assessed more positively by male voters than female voters, and female party leaders are assessed more positively by female voters than male voters $\left(\mathrm{H}_{1}\right)$. However, exploring the campaign effect is impossible due to the lack of data.

Table 6 shows voters' assessment of the characteristics of the female and male party leaders. This shows, first, that on average female party leaders are assessed more positively than male party leaders regardless of the voters' gender (comparing columns 1 and 2 with 3 and 4). There is just one significant exception to this and this is that men find male party leaders more knowledgeable than female leaders (5.17 to 5.31). Secondly, female voters consistently and significantly assess female party leaders more positively on all eight characteristics compared to male party leaders (comparing columns 1 and 3) ${ }^{9}$. However, the trend is less consistent in regard to male voters' assessments of female and male party leaders. Male party leaders are on average regarded to be more knowledgeable and qualified to be Prime Ministers, whereas men score female leaders higher on the remaining characteristics. Hence, again, support is primarily found for the latter part of the hypothesis that male party leaders are assessed more positively by male voters than female voters, and female party leaders are assessed more positively by female voters than male voters $\left(\mathrm{H}_{1}\right)$. 
Table 6 Voters' assessments of party leaders before the campaign, 0-10 scale

\begin{tabular}{lcccc}
\hline & \multicolumn{2}{c}{ Female party leaders } & \multicolumn{2}{c}{ Male party leaders } \\
& Women & Men & Women & Men \\
\hline Trustworthy & 5.35 & 5.02 & 4.47 & 4.54 \\
& {$[5.29-5.40]$} & {$[4.97-5.08]$} & {$[4.42-4.52]$} & {$[4.49-4.59]$} \\
Inspiring & 4.70 & 4.39 & 3.92 & 4.16 \\
& {$[4.65-4.76]$} & {$[4.34-4.44]$} & {$[3.88-3.97]$} & {$[4.11-4.21]$} \\
Knowledgeable & 5.64 & 5.17 & 5.29 & 5.31 \\
& {$[5.58-5.69]$} & {$[5.11-5.22]$} & {$[5.23-5.34]$} & {$[5.25-5.36]$} \\
Aware of common people's & 5.17 & 4.82 & 4.34 & 4.29 \\
opinions and thoughts & {$[5.12-5.23]$} & {$[4.77-4.87]$} & {$[4.28-4.39]$} & {$[4.24-4.34]$} \\
Sincere & 6.13 & 5.86 & 4.89 & 5.09 \\
& {$[6.07-6.19]$} & {$[5.80-5.92]$} & {$[4.83-4.94]$} & {$[5.04-5.15]$} \\
Qualified for being the Prime & 3.56 & 3.10 & 3.38 & 3.49 \\
Minister & {$[3.50-3.61]$} & {$[3.05-3.16]$} & {$[3.33-3.43]$} & {$[3.44-3.54]$} \\
Good leader & 5.19 & 4.78 & 4.47 & 4.55 \\
& {$[5.13-5.26]$} & {$[4.72-4.84]$} & {$[4.41-4.53]$} & {$[4.50-4.60]$} \\
Personal Charisma & 5.73 & 5.47 & 4.12 & 4.42 \\
& {$[5.67-5.79]$} & {$[5.41-5.52]$} & {$[4.07-4.17]$} & {$[4.37-4.47]$} \\
\hline$N$ & 4,217 & 4,294 & 4,217 & 4,294 \\
\hline
\end{tabular}

Note: Means with $95 \%$ confidence intervals.

The analysis in Table 6 is without control for party sympathy, whereas the models in Table 7 control for party sympathy. In the model for male party leaders in Table 7 we find no difference across voters' gender whereas all eight characteristics significantly relate to party leader sympathy. It is interesting that the characteristics of "knowledgeable" and "sincere" are associated with less male leader sympathy. For female party leaders, there are gender differences in voters' assessment, corresponding to the analyses above. All characteristics, except "being knowledgeable", are significantly related to voters' female party leader sympathy. As is the case for male leaders, "sincerity" is associated with less female party leader sympathy; however, all other characteristics contribute positively to female party leader sympathy. In regard to "sincere" and "being knowledgeable" these characteristics have the smallest effects when the other characteristics are included in the models. For both male and female party leaders the characteristic "qualified for being the Prime Minister" is the characteristic that most strongly associates with party leader sympathy. 
Table 7 Modeling the party leader sympathy as a function of characteristics (controlled for party sympathy)

\begin{tabular}{|c|c|c|}
\hline & $\begin{array}{l}\text { Male party leaders } \\
\text { (before) }\end{array}$ & $\begin{array}{c}\text { Female party } \\
\text { leaders (before) }\end{array}$ \\
\hline Women & $\begin{array}{c}0.0138 \\
(0.02)\end{array}$ & $\begin{array}{c}0.0822 * * * \\
(0.02)\end{array}$ \\
\hline Trustworthy & $\begin{array}{c}0.198 * * * \\
(0.01)\end{array}$ & $\begin{array}{c}0.197 * * * \\
(0.01)\end{array}$ \\
\hline Inspiring & $\begin{array}{c}0.135 * * * \\
(0.02)\end{array}$ & $\begin{array}{c}0.178 * * * \\
(0.01)\end{array}$ \\
\hline Knowledgeable & $\begin{array}{c}-0.0248 * * \\
(0.01)\end{array}$ & $\begin{array}{c}0.00278 \\
(0.01)\end{array}$ \\
\hline Aware of common people's opinions and thoughts & $\begin{array}{c}0.0269^{* *} \\
(0.01)\end{array}$ & $\begin{array}{c}0.0357 * * * \\
(0.01)\end{array}$ \\
\hline Sincere & $\begin{array}{c}-0.0400 * * * \\
(0.01)\end{array}$ & $\begin{array}{c}-0.0299 * * * \\
(0.01)\end{array}$ \\
\hline Qualified for being the Prime Minister & $\begin{array}{c}0.0863 * * * \\
(0.01)\end{array}$ & $\begin{array}{c}0.0865 * * * \\
(0.01)\end{array}$ \\
\hline Good leader & $\begin{array}{l}0.0736^{* * * *} \\
(0.01)\end{array}$ & $\begin{array}{l}0.0501 * * * \\
(0.01)\end{array}$ \\
\hline Personal Charisma & $\begin{array}{c}0.120 * * * \\
(0.01)\end{array}$ & $\begin{array}{c}0.109 * * * \\
(0.01)\end{array}$ \\
\hline Party sympathy & $\begin{array}{c}0.421 * * * \\
(0.01)\end{array}$ & $\begin{array}{c}0.397 * * * \\
(0.01)\end{array}$ \\
\hline Constant & $\begin{array}{c}0.0135 \\
(0.03)\end{array}$ & $\begin{array}{c}-0.119 * * * \\
(0.03)\end{array}$ \\
\hline $\begin{array}{l}N \\
R^{2}\end{array}$ & $\begin{array}{l}7,694 \\
0.758\end{array}$ & $\begin{array}{l}7,694 \\
0.798\end{array}$ \\
\hline
\end{tabular}

Note: OLS-regression, unstandardized coefficients, robust standard errors in parentheses. ${ }^{*} p<0.10,{ }^{* * *} p<0.05,{ }^{* * * *} p<$ $0.01, \mathrm{VIF}=3.4$ and 3.6 indicating no problem of multicollinearity.

Testing the full set of interactions between gender and all characteristics do not contribute significantly to the models, which implies that men and women assess party leader characteristics similarly in relation to party leader sympathy.

\section{Conclusion}

To what extent did gender differences exist in Danish voters' assessments of party leaders before and after the 2011 general election campaign?

Only the latter part of the hypothesis that male party leaders are assessed more positively by male voters than female voters, and female party leaders are assessed more positively by female voters than male voters $\left(\mathrm{H}_{1}\right)$ is supported throughout the analyses. Gender affects voters' female party leader sympathy both before the campaign and after the election. 
Turning to the exploration of the impact of age, education, interest and knowledge on voters' party leader sympathy, the analysis reveals that age, education, political knowledge and interest have an effect on voters' sympathy for female party leaders, primarily before the campaign. However, the effect of this is not enlarged by gender; hence, we find no support for the hypotheses that the older the voter, the more positive the voter is towards party leaders of their own gender $\left(\mathrm{H}_{2}\right)$, that voters with more education are more positive towards party leaders of their own gender than voters with less education $\left(\mathrm{H}_{3}\right)$, and that the more political interest and knowledge a voter has, the more positively the voter perceives party leaders of his or her own gender $\left(\mathrm{H}_{4}\right)$. Contrary to what was expected, younger men have less sympathy with female party leaders, hence, there may a gender awareness with a different basis than older voters' socialization at a time of maledomination in politics. This could point towards a reawakening of gender biases and certainly calls for the inclusion of both genders on both the independent and dependent variables when conducting such studies.

The effect of gender does not change from before the campaign to after the election. Hence, no support is found for the hypothesis that gender has a larger effect on voters' assessments of party leaders before the election campaign than after election day $\left(\mathrm{H}_{5}\right)$. But the impact of education and political interest does become insignificant, which could indicate that during campaigns, voters acquire knowledge about party leaders' personalities and competencies whereby they are better equipped to assess party leaders. Since gender has an impact on assessments of female party leaders both before and after the election, it could be argued that the effect of campaigns is not that the vast amount of political information makes voters less likely to rely on the gender shortcut but that it sustains voters' gender identity, at least when it comes to female party leaders. And not only for women but also for younger men who sympathize with female leaders to a lesser extent than older men.

Party leader sympathy is a general assessment, and the electorate's assessment of specific party leader characteristics are included to allow for a more detailed assessment. At the level of specific characteristics, results support the hypothesis that male voters assess male party leaders more positively than female voters and female voters assess female party leaders more positively than male voters $\left(\mathrm{H}_{1}\right)$ both at the aggregate level and for each party leader.

However, this study may not have addressed the only gender-related campaign effects. Further studies could analyze the media coverage of party leaders and explore whether the amount and type of media coverage about party leaders during the campaign affect the voters' sympathy toward party leaders and assessment of leaders' characteristics (see Gidengil \& Everitt 1999, 2000, 2003a, 2003b; van Zoonen 1998, 2006). Such studies could further contribute to what voter considerations in regard to gender stereotyping and gender identity are present during campaigns. Also, further studies could dig into the relationship between voters' sympathy for the party and its party leader by investigating the voters' image of the party, and the party leader's part of this. 
In conclusion, this study demonstrates that gender differences in voters' assessments of party leaders are found even in this less likely Danish case, which implies that the gender of party leaders affects voters' assessments of them and hence also possibly their party choice. As party leaders become more important even in multiparty, party-centered systems, gender and other characteristics of party leaders are becoming more important as well.

\section{References}

Alexander, D. \& Andersen, K. 1993. Gender as a Factor in the Attribution of Leadership Traits. Political Research Quarterly, Vol. 46, No. 3 (Sep., 1993), pp. 527-545.

Andersen, J. \& Andersen, J.G. 2003. 'Køn, alder og uddannelse: De unge mænds sejr,' in Andersen, J.G. \& Borre, O. eds. Politisk Forandring. Vardipolitik og nye skillelinjer ved folketingsvalget 2011. Aarhus: Systime.

Andersen, J. \& Borre, O. 2007. 'Partiledere gør en forskel', in Andersen, J.G., Andersen, J., Borre, O., Hansen, K.M. \& Nielsen, H.J. eds. Det nye politiske landskab. Folketingsvalget $2005 i$ perspektiv. Århus: Academica, pp. 289-306.

Banducci, S. 2002. 'Gender and Leadership', in Vowles, J., Aimer, P., Karp, J., Banducci, S., Miller, R. \& Sullivan, A. eds. Proportional Representation on Trial: The 1999 New Zealand General Election and the Fate of MMP. Auckland: Auckland University Press.

Banducci, S.A. \& Karp, J.A. 2000. 'Gender, Leadership and Choice in Multiparty Systems', Political Research Quarterly 53, 4, 815-848.Bengtsson, Å., Hansen, K. H., Harõarson, Ó. P. , Narud, H. M., \& Oscarsson, H. 2013. The Nordic Voter. Myths of Exceptionalism. London: ECPR Press.

Bergqvist, C., Borchorst, A., Christensen, A., Ramstedt-Silén, V., Raaum, N.C. \& Styrkársdóttir, A. eds. 1999. Equal Democracies? Gender and Politics in the Nordic Countries. Oslo: Scandinavian University Press.

Bille, L. 1997. Partier i forandring. Odense: Odense Universitetsforlag.

Bittner, A. 2011. Platform or Personality? The Role of Party Leaders in Elections. Oxford: Oxford University Press.

Bittner, A. undated. Evaluating Party Leaders: How Demographics, Partisanship, Policies and Issues Affect Voters' Opinion. Located February $18^{\text {th }} 2014$ at https://www.academia.edu/423646/Evaluating_Party_Leaders_How_Demographics_Partisanship_P olicies_and_Issues_Affect_Voters_Opinions.

Borchorst, A. 2011. Scandinavian Gender Equality: Competing Discourses and Paradoxes', in Addis, E., Villota, P.de., Degavre, F. \& Eriksen, J. eds. Gender and well-being. The Role of Institutions. Farnham: Ashgate. 63-75.

Campus, D. 2013. Women Political Leaders and the Media. Basingstoke: Palgrave Macmillan Ltd. 
Carroll, S. 1988. 'Women's Autonomy and the Gender Gap: 1980 and 1982', in Carol M. Mueller, ed., The Politics of the Gender Gap. Beverly Hills: Sage Publications.

Carty, R. K. 2004. Parties as Franchise Systems: The Stratarchical Organizational Imperative Party Politics, Vol. 10, No. 1, pp. 5-24.

Christensen, A. 1999. 'Women in the political parties', in Bergqvist, C., Borchorst, A., Christensen, A., Ramstedt-Silén, V., Raaum, N.C. \& Styrkársdóttir, A. eds. Equal Democracies? Gender and Politics in the Nordic Countries. Oslo: Scandinavian University Press.

Craig, S.C., Kane, J.G. \& Gainous, J. 2005. 'Issue-Related Learning in a Gubernatorial Campaign: A Panel Study', Political Communication, 22, 483-503.

Cutler, F. 2002. 'The Simplest Shortcut of All: Sociodemographic Characteristics and Electoral Choice', The Journal of Politics 64, 2, 466-490.

Denemark, D., Ward, I. \& Bean, C. 2012. 'Gender and Leader Effects in the 2010 Australian Election', Australian Journal of Political Science, 47, 4, 563-578.

Dolan, K. 1998. 'Voting for Women in the "Year of the Woman", American Journal of Political Science, 42, 1, 272-293.

Erickson, L. 2003. 'In the Eyes of the Beholder: Gender and Leader Popularity in a Canadian Context', in Tremblay, M. \& Trimble, L. eds. Women and Electoral Politics in Canada. Oxford: Oxford University Press.

Freedman, P., Franz, M. \& Goldstein, K. 2004. 'Campaign Advertising and Democratic Citizenship', American Journal of Political Science, 48, 723-741.

Folketinget. 2014. Kvindeprocenten i Folketinget. Located February $18^{\text {th }} 2014$ at http://www.ft.dk/Folketinget/Oplysningen/Folketingsmedlemmer/Kvindeprocenten.aspx

Garzia, D. 2011. 'The personalization of politics in Western democracies: Causes and consequences of leader-follower relationships', The Leadership Quarterly, 22, 4, 697-709.

Gidengil, E. \& Everitt, J. 1999. Metaphors and misrepresentation: Gendered mediation in news coverage of the 1993 Canadian leaders' debates. Press/Politics, 4 (1) 48-65.

Gidengil, E. \& Everitt, J. 2000. Filtering the female: Television news coverage of the 1993 Canadian leaders' debates. Women \& Politics 21 (4) 105-131.

Gidengil, E. \& Everitt, J. 2003a. Conventional coverage/unconventional politicians: Gender and media coverage of Canadian leaders' debates. Canadian Journal of Political Science, 36 (3).

Gidengil, E. \& Everitt, J. 2003b. Talking Tough: Gender and Reported Speech in Campaign News Coverage. Political Communication 20, 209-232.

Giger, N., Holli, A.M., Lefkofridi, Z. \& Wass, H. 2014. 'The gender gap in same-gender voting: The role of Context'. Electoral Studies. http://dx.doi.org/10.1016/j.electstud.2014.02.009.

Hansen, J.H. 2014. Valgkampens betydning for de personlige stemmer, in Hansen, K.M. \& Kosiara-Pedersen, K. eds. Folketingsvalgkampen 2011 i perspektiv. København: DJØF-forlag. 
Hansen, K.M., Kosiara-Pedersen, K. \& Pedersen, R.T. 2012. Facts about the survey. CVAP Working paper.

Hansen, K.M. \& K. Kosiara-Pedersen. Forthcoming. Polarization within a Multiparty System.

Hansen, K.M. \& Pedersen, R.T. 'Campaigns Matter: How Voters Become Knowledgeable and Efficacious During Election Campaigns'. Political Communication.

Hayes, B. \& McAllister, I. 1997. 'Gender, Party Leaders and Election Outcomes in Australia, Britain and the United States', Comparative Political Studies 30, 3-26.

Heidar, K. \& Pedersen, K. 2006. 'Party Feminism: Gender Gaps within Nordic Political Parties.' Scandinavian Political Science 29, 3, 192-218.

Hershey, M. R. 1980. 'Support for Political Woman: The Effects of Race, Sex, and Sexual Roles.' In John C. Pierce and John L. Sullivan, eds., The Electorate Reconsidered. Beverly Hills: Sage.

Hershey, M. R. 1977. 'The Politics of Androgeny? Sex Roles and Attitudes Toward Women in Politics.' American Politics Quarterly 5: 261-88.

Holli, A.M. \& Wass, H. 2010. 'Gender-based voting in the parliamentary elections of 2007 in Finland', European Journal of Political Research. 9, 5, 598-630.

Huddy, L. \& Terkildsen, N. 1993a. 'Gender Stereotypes and the Perception of Male and Female Candidates', American Journal of Political Science, 37, 117-47.

Huddy, L. \& Terkildsen, N. 1993b. 'The Consequences of Gender Stereotypes for Women Candidates at Different Levels and Types of Office', Political Research Quarterly, 46, 3, 503-525.

Inglehart, R. \& Norris, P. 2000. The Developmental Theory of the Gender Gap: Women and Men's Voting Behavior in Global Perspective'. International Political Science Review. 21, 441-463.

Johns, R. \& Shephard, M. 2007. 'Gender, Candidate Image and Electoral Preference', British Journal of Politics and International Relations, 9, 434-460.

Kahn, K. F. 1994. 'Does Gender Make a Difference? An Experimental Examination of Sex Stereotypes and Press Patterns in Statewide Campaigns', American Journal of Political Science, 38, $1,162-195$.

Karvonen, L. 2010. The Personalisation of Politics: A Study of Parliamentary Democracies. Colchester: ECPR Press.

Matland, R. E. 1994. 'Putting Scandinavian Equality to the Test: An Experimental Evaluation of Gender Stereotyping of Political Candidates in a Sample of Norwegian Voters', British Journal of Political Science, 24, 2, 273-292.

Okimoto, T. \& Brescoll, V. 2010. 'The Price of Power: Power Seeking and Backlash against Female Politicians. Personality and Social Psychology Bulletin, 36, 923-936.

O'Neill, B. 1998. 'The Relevance of Leader Gender to Voting in the 1993 Canadian National Election', International Journal of Canadian Studies 17: 105-30. 
O’Neill, B. \& Stewart, D.K. 2009. 'Gender and Political Party Leadership in Canada', Party Politics, 15, 6, 737-757.

Pedersen, K. 2003. Party Membership Linkage: The Danish Case. København: Institut for Statskundskab, Københavns Universitet.

Pitkin, H. 1967. The Concept of Representation. Berkeley: University of California Press.

Plutzer, E. \& Zipp J.F. 1996. 'Identity Politics, Partisanship, and Voting for Women Candidates', Public Opinion Quarterly 60, 30-57.

Poguntke, T. \& Webb, P. 2005, eds. The Presidentialization of Politics. A Comparative Study of Modern Democracies. Oxford: Oxford University Press.

Pomper, G. 1975. Voter's Choice. New York: Harper \& Row.

Raaum, N.C. 2004. 'Chapter 9: The Presence of Women in Parliamentary Politics' in Heidar, K. ed. Nordic Politics. Oslo: Universitetsforlaget.

Rosenthal, C.S. 1995. 'The Role of Gender in Descriptive Representation', Political Research Quarterly, 48, 3, 599-611.

Sanbonmatsu, K. 2002. Democrats, Republicans, and the Politics of Women's Place. Ann Arbor: University of Michigan Press.

Schneider, M.C. \& Bos, A.L. 2013. Measuring Stereotypes of Female Politicians. Political Psychology. DOI: 10.1111/pops.12040.

Stubager, R. \& Hansen, K.M. 2013. 'Social Baggrund og partivalg' in Stubager, R., Hansen, K.M. \& Andersen, J.G. eds. Krisevalg. Økonomien og folketingsvalget 2011. København: DJØF-forlag, pp. 61-88.

Studlar, D.T., McAllister, I. \& Hayes, B.C. 1998. 'Explaining the gender gap in voting: A crossnational analysis', Social Science Quarterly, 79, 4, 779-798.

Thomsen, S.R. 2003. 'En samlet model for partivalg', in Andersen, J.G. \& Borre, O. eds. Politisk Forandring. Vaerdipolitik og nye skillelinjer ved folketingsvalget 2011. Aarhus: Systime, pp. 25177.

Togeby, L. 1994. 'The Disappearance of a Gender Gap: Tolerance and Liberalism in Denmark from 1971-1990'. Scandinavian Political Studies, 14, 1, 47-68.

van Zoonen, L. 1998. 'Finally I Have My Mother Back: Male and Female Politicians in Popular Culture'. Harvard International Journal of Press/Politics, 3, 1, 48-64.

van Zoonen, L. 2005. Entertaining the Citizen: When Politics and Popular Culture Converge. Boulder, Colorado: Rowman and Littefield.

van Zoonen, L. 2006. 'The personal, the political and the popular. A woman's guide to celebrity politics'. European Journal of Cultural Studies 9, 3, 287-301. 
Wauters, B., Marien, S. \& Schouteden, A. 2013. Gender-based voting in Belgium's flexible list system: Gender affinity effect or party effect? Paper presented at ECPR Joint Sessions, Mainz 2013.

\author{
Wattenberg, M. 1991. The Rise of Candidate-Centered Politics. Cambridge, Massachusetts: \\ Harvard University Press.
}

Zipp, J.F. \& Plutzer, E. 1985. 'Gender Differences in Voting for Female Candidates: Evidence From the 1982 Election', Public Opinion Quarterly 79, 2, 179-97.

\footnotetext{
${ }^{1}$ We are deeply grateful for the invaluable comments provided by the three SPS reviewers who offered constructive comments on the first versions of this manuscript, and to Karsten Vestergaard for thorough and prompt research assistance.

${ }^{2}$ Department of Political Science, University of Copenhagen, Østre Farimagsgade 5, DK-1353 København K.kmh@ifs.ku.dk/kp@ifs.ku.dk

${ }^{3}$ Although other studies have noted the relevance of differences between sex and gender, the terms sex/gender, $\mathrm{man} / \mathrm{male}$ and woman/female are used interchangeably in this study.

${ }^{4}$ The Social Democrats and the Socialist People's Party previously had gender quotas both within the party organization and when nominating candidates for elections. The Social Democrats have gender quotas for party leadership since both genders must be represented among the party leader and the two vice leaders.

${ }^{5}$ This is true except for two single-MP parties, the Christian Democrats and Focus, which were represented in the 2007 2011 term.

${ }^{6}$ Three shifts have taken place since the 2011 election: Pia Kjærsgaard stepped down in September 2012 and was replaced by the male vice-chair and crown prince, Kristian Thulesen Dahl. In 2012, the members of the Socialist People's Party elected a female chair, Annette Wilhelmsen, in a contested election between two female candidates. She stepped down and was replaced by another woman, Pia Olsen Dyhr, in an uncontested election in February 2014. ${ }^{7}$ The party leaders of both the Socialist People's Party and Social Democrats were elected by rank-and-file party membership in contested membership ballots in 2005. Villy Søvndal defeated a female candidate, whereas Helle Thorning-Schmidt defeated a male candidate. Although formally elected unanimously at each annual party conference since 1996, Pia Kjærsgaard (DPP) is better classified as party owner than leader; the party was created when she, together with a small group, split from the Progress Party in 1995. Anders Samuelsen (LA) could also be classified as a party owner but is confirmed by the parliamentary group. A former MEP (SL), together with MP Naser Khader (SL) and MEP Gitte Seeberg (CPP), he created the party New Alliance in 2007. Since then, the other two creators have left the party, new colleagues have joined and the party name has changed. The parliamentary groups are also decisive among the Conservatives and Liberals because both their present leaders have been selected by the parliamentary groups - selections that have been confirmed by the party organization at the annual party conferences. Conservative Lars Barfoed replaced female Lene Espersen in January 2011 due to her bad standing in the polls, bad publicity and the party's urge to do something. The party leader of the Social Liberals is formally selected by the parliamentary group. The Red-Green Alliance deserves special attention because they do not have a political leader due to their grass roots organizational structure. However, due to the pressure of media-driven politics, in 2009 they chose to select a political spokesperson, Johanne Schmidt-Nielsen, who still holds this position. Prior to that time, the small parliamentary group had split the assignments commonly attributed to a party leader, such as representing the party in political debates.

${ }^{8}$ The survey was conducted by TNS Gallup for the project Online Panel of Electoral Campaigning (OPEC), financed by a grant from the Danish Council for Independent Research | Social Sciences (FSE) to Kasper M. Hansen (project leader), Karina Kosiara-Pedersen and Rasmus Tue Pedersen, Department of Political Science, University of Copenhagen (http://www.cvap.polsci.ku.dk/valgkamp/).

${ }^{9}$ These eight characteristics for male and female and together all load on a single factor when applying factor analysis which indicate that the characteristics are highly related in the eyes of the voters.
} 